\title{
THE ANIMAL REMAINS FROM THE LATE ROMAN AND EARLY MIGRATION PERIOD SETTLEMENTS AT VRBOV AND LAZISKO (NORTHERN SLOVAKIA) ${ }^{1}$
}

\author{
Z O R A B I E L I C H O VÁ
}

\begin{abstract}
The aim of the contribution is to present the very first information on the animal remains from the North Carpathian Group unfortified settlements $\left(4^{\text {th }}-5^{\text {th }} \mathrm{c}\right.$. AD) of northern Slovakia. Although the analysed sample size is small - 348 specimens in total - it sheds light on animal husbandry, hunting and the animal-based diet of these populations. Despite their different natural settings, the riverine settlement at Vrbov-Vrbovský lesík (Kežmarok distr.) and the hilltop settlement at Lazisko-Zvon (Liptovský Mikuláš distr.) showed the same dependence on domestic livestock with a focus on cattle (Bos taurus) and caprines (Ovis/Capra). The higher age-at-slaughter of both species suggested they were most probably of mixed utility, i.e. they produced meat, milk and wool. At both sites, pigs (Sus domesticus) occurred in low numbers. The butchered horse bones (Equus caballus) from Lazisko indicated that horse meat was occasionally consumed. Results also suggested that wild mammals played a negligible role in either subsistence terms or the economy. The find of a brown bear tooth from Lazisko, most probably an amulet, reflects the sporadic hunting activities that did take place.
\end{abstract}

Keywords: Slovakia, Late Roman, Early Migration Period, North Carpathian group, archaeozoology, diet.

\section{INTRODUCTION}

Archaeologists exploit many sources of information while trying to solve their 'ancient puzzles'. In the spring of 2021, during writing a book about the discovery of the extraordinary chieftain's grave in Poprad-Matejovce (e.g. Lau/Pieta 2014; Štolcová et al. 2014), Karol Pieta entered my lab with two boxes of animal bones connected to his past research activities in Liptov and Spiš. Both of these small but unique materials were supposed to shed more light on the subsistence of the people who had entombed their 'prince' in Poprad. During the Late Roman and Early Migration periods when the burial took place, the mountains and valleys of northern Slovakia and southern Poland were inhabited by the so-called North Carpathian group people (Pieta 1991; 2008). They probably engaged in a mixture of agriculture and livestock herding with a distinctive activity connected to mining, iron smithing, pottery or textile production, bone-working and trade (Béreš et al. 1991; Budinský-Krička 1963; Lamiová-Schmiedlová 1964; Madyda-Legutko/Tunia 1993; Pieta 1991; 2008). Their characteristic material culture appears in sites located on both sides of the Carpathian passes with strong similarities with the material culture of the final phase of the Przeworsk Culture and the
Ostrovany-Blažice late Roman group in eastern Slovakia. Some artefacts display evidence of contacts with the disintegrating Chernyakhov-Sântana de Mureş complex in southeast Slovakia and Pannonia Province (Pieta 1991, 385).

The archaeobotanical research in southern Poland showed that the North Carpathian group were primarily made up of settled populations involved in cultivation of cereals such as barley, rye, bread wheat, emmer wheat, spelt or millet (e.g. Lityńska-Zajac 1993; Madyda-Legutko/Tunia 1993, 98). Finds of sickles, scythes, coulters or massive knives occurred (e.g. Pieta 1991). This paper provides the very first insight into animal husbandry of these people and the part of their diet that was animalbased diet. On the basis of analysis of the small bone assemblages from Vrbov (Kežmarok distr.) and Lazisko (Liptovský Mikuláš distr.) I tried to answer the following research questions: What animals did the North Carpathian populations exploit? Did they keep and bred animals locally? What was the meat diet of the locals? Was the diet comparable to other Late Roman and Early Migration period (Germanic) settlements within the area of Slovakia? Did they hunt for meat? What did their domestic animals look like? And what was the use of the animals?

\footnotetext{
1 This work has been supported by the National Scientific Grant Agency VEGA no. 2/0001/18. I am indebted to Alice M. Choyke from the Central European University in Vienna for valuable comments and corrections of English.
} 


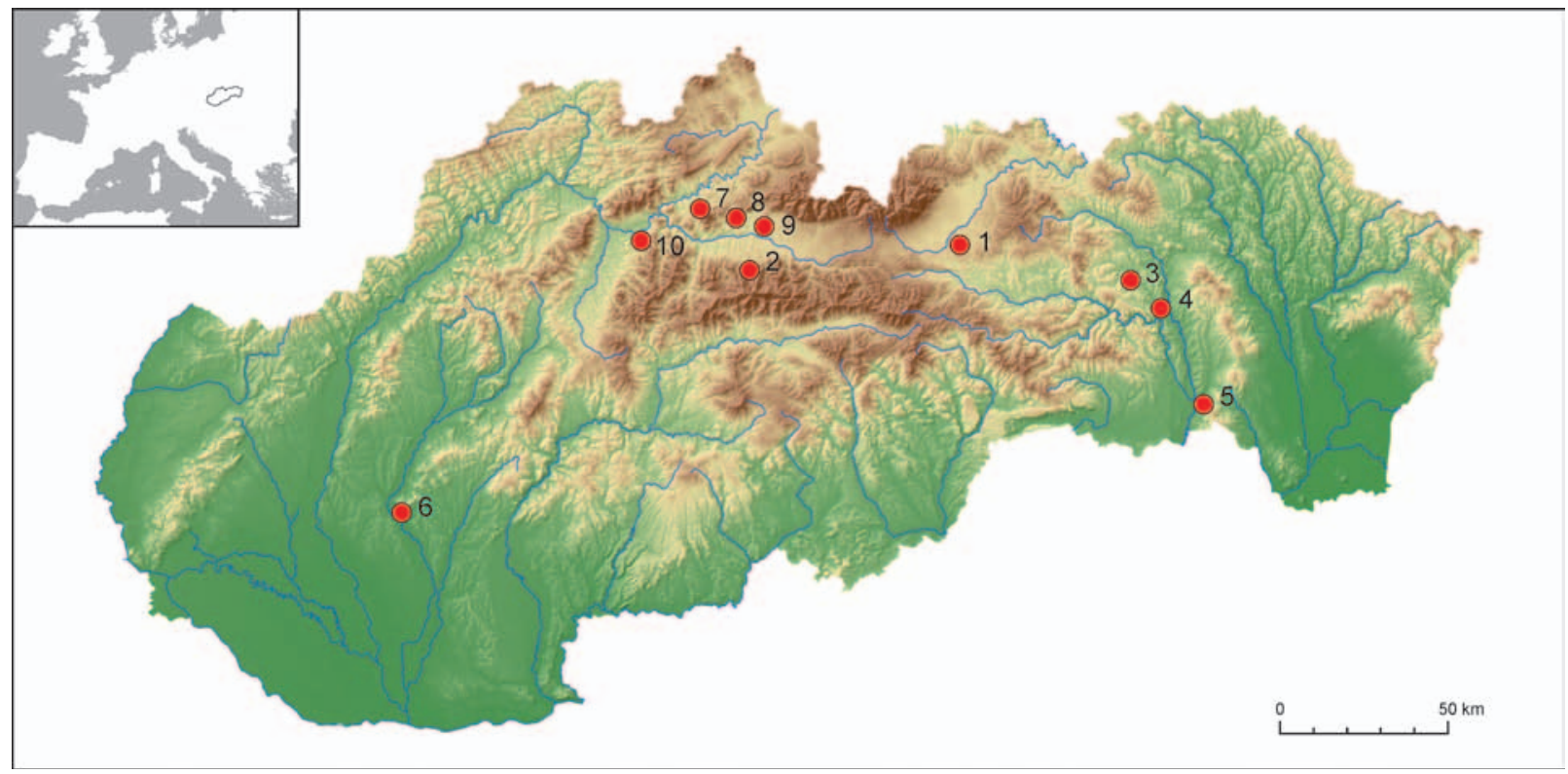

Fig. 1. The archaeological sites from Slovakia considered in the text. The Late Roman and Early Migration period settlements: 1 - Vrbov-Vrbovský lesík; 2 - Lazisko-Zvon; 3 - Ostrovany-Pri kaštieli and dom F. Štelbackého; 4 - PrešovPavlovičovo námestie; 5 - Nižná Myšla-Alamenev; 6 - Nitra-Párovské Háje. The Iron Age settlements: 7 - Vyšný Kubín; 8 - Kvačany; 9 - Liptovská Sielnica-Liptovská Mara; 10 - Sučany (author P. Červeň).

\section{MATERIAL AND METHODS}

While the artefacts from the open settlement at Vrbov-Vrbovský lesík (Kiefer/Kolnik 1995) and the hilltop settlement at Lazisko-Zvon (850 m a.s.l.; Pietal Hanuliak 1988) belong to relatively well-known (e.g. Giertlová-KučerákoválSoják 2002; 2005; Pieta 1991; 2008; Soják 2015), the information on ecofacts have so far been missing. The archaeofaunal remains from, the excavation at Vrbov-Vrbovský lesík supervised by L. Kiefer, F. Javorský and K. Pieta in 1985, included 10 samples retrieved from unspecified features and cultural layers (Bielichová 2021a). The bone material from Lazisko-Zvon, excavated by K. Pieta in 1989, comprised 13 samples from unspecified cultural layers (Bielichová 2021b). In total, 22 archaeozoological samples including 348 specimens were analysed.

Due to the rescue character of the excavation, no systematic environmental sampling was carried out. ${ }^{2}$ The archaeofaunal material consists only of large and medium-sized bones of vertebrates. The majority of skeletal elements were fragmented before deposition and display old fractures. Except for short bones such as the phalanges, carpalialtarsalia or the teeth, no complete element was recorded. The bone surfaces were relatively well preserved.
The archaeozoological analysis followed standard methods. The identification process employed a basic visual-comparative method and a magnifier lamp with low resolution $(1.75 \times$ mag.). The archaeological and modern reference material housed at the archaeozoological laboratory of the Institute of Archaeology of the Slovak Academy of Sciences in Nitra and relevant identification manuals were used (e.g. Kolda 1936; Schmid 1972). The unidentified specimens were assigned to the auxiliary 'taxonomic' groups of medium- (MM) and large-sized (LM) mammals. The approximate age at slaughter/ death of animals was estimated on the basis of dental eruption/abrasion and the fusion stage of the long bone epiphyses (criteria from Habermehl 1961; Silver 1969). Natural or artificial bone modifications were classified according to R. L. Lyman (1994). Measurements, taken by slide callipers with the accuracy of $0.1 \mathrm{~mm}$, were recorded after $A$. von den Driesch (1976). The withers height of sheep was calculated on the basis of a formula introduced by M. Teichert (1975).

The quantitative results were evaluated following the primary methods including the number (NISP) and weight (WISP) of identified specimens. Due to the overall low number of finds and rescue character of the excavations, results are presented as a unit

\footnotetext{
2 A few daub samples with plant imprints and two soil samples from Vrbov and Lazisko have been analysed in 2021 by Jana Mihályiová from the IA SAS in Nitra.
} 
Tab. 1. Vrbov-Vrbovský lesík. Taxonomic and anatomic determination. Quantified by NISP.

\begin{tabular}{|c|c|c|c|c|c|c|c|c|c|c|c|c|c|c|c|c|c|c|c|c|c|c|}
\hline Vrbov & ટ્ & 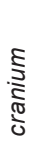 & 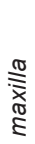 & 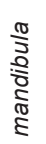 & $\begin{array}{l}\frac{\infty}{d} \\
\frac{d}{0}\end{array}$ & $\begin{array}{l}\frac{\pi}{0} \\
\frac{0}{2} \\
\frac{9}{2}\end{array}$ & $\begin{array}{l}\frac{\pi}{\omega} \\
\text { ర్ } \\
0\end{array}$ & $\begin{array}{l}\frac{\pi}{3} \\
\frac{2}{\pi} \\
\tilde{\omega}\end{array}$ & 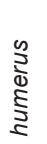 & 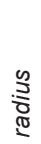 & 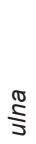 & $\stackrel{\infty}{\frac{\infty}{\infty}}$ & $\stackrel{\frac{\pi}{2}}{2}$ & 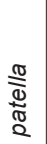 & 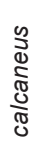 & $\stackrel{\mathscr{S}}{\Phi}$ & 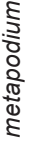 & 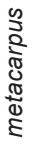 & 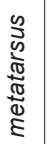 & $\begin{array}{l}\frac{x}{d} \\
\frac{x}{\mathbb{D}} \\
\frac{\tilde{D}}{2}\end{array}$ & $?$ & Total \\
\hline Bos taurus & - & - & 2 & 1 & 14 & - & - & - & - & - & - & 1 & - & - & - & 1 & - & - & 1 & 2 & - & 22 \\
\hline cf. Bos taurus & - & - & - & - & - & 1 & 3 & 1 & 1 & 1 & - & - & 3 & - & - & - & - & - & - & 1 & - & 11 \\
\hline Bos sp. & - & - & - & - & - & - & - & - & - & - & - & - & - & - & - & - & - & - & - & 1 & - & 1 \\
\hline Ovis aries & 1 & - & - & - & - & - & - & - & - & - & - & - & - & - & - & - & - & 2 & - & - & - & 3 \\
\hline Ovis/Capra & - & - & - & 2 & 19 & - & - & - & - & - & - & 1 & - & - & 1 & - & - & 1 & - & - & - & 24 \\
\hline cf. Ovis/Capra & - & 2 & - & 5 & - & 1 & - & - & 1 & - & - & - & - & - & - & - & 1 & - & - & - & - & 10 \\
\hline Sus domesticus & - & - & 1 & 2 & 7 & - & - & - & - & - & 1 & - & 3 & 1 & - & 1 & - & - & - & - & - & 16 \\
\hline Unidentified MM & - & - & - & - & - & 1 & 1 & - & - & - & - & - & - & - & - & - & - & - & - & - & 6 & 8 \\
\hline Unidentified MM/LM & - & - & - & - & - & - & 3 & - & - & - & - & - & - & - & - & - & - & - & - & - & 23 & 26 \\
\hline Unidentified LM & - & - & - & - & - & 1 & - & - & - & - & - & 1 & - & - & - & - & - & - & - & - & 11 & 13 \\
\hline Total & 1 & 2 & 3 & 10 & 40 & 4 & 7 & 1 & 2 & 1 & 1 & 3 & 6 & 1 & 1 & 2 & 1 & 3 & 1 & 4 & 40 & 134 \\
\hline
\end{tabular}

per site and not sub-sampled within the explored areas (soundings/features). The only exception was feature 1 at Vrbov and sounding 1-location 11 at Lazisko, where, in addition to NISP and WISP, the minimum number of individuals (MNI) have been estimated. To increase the number of finds of particular species, the totals for domestic animals such as cattle, caprines and pig also include specimens of the tentative identification (cf. Bos taurus and cf. Ovis/Capra).

The results from Vrbov and Lazisko were compared to all available (published and unpublished) archaeozoological data from the Late Roman and Early Migration settlements in Slovakia (Fig. 1). In the east, bone assemblages dated to the $3^{\text {rd }}-5^{\text {th }} \mathrm{c}$. AD were unearthed at Ostrovany, located in 'Pri kaštieli' and 'Dom F. Štelbackého' (Lamiová-Schmiedlová 1964), at Prešov, located in 'Pavlovičovo námestie' (Budinský-Krička 1963) and at Nižná Myšla, located in 'Alamenev' (Béreš et al. 1991). According to the archaeologists, these sites represent the limits of the North Carpathian Group settlement area. ${ }^{3}$ The archaeozoological analyses were carried out by C. Ambros (1960; 1961; 1962) and V. Rajtová (1964; 1991). In the southwest, information about archaeofauna was only available from the analysis carried out by C. Ambros (1986). The animal bone material, recovered from the ash pit of the pottery kiln and three refuse pits in Nitra, located in 'Párovské Háje', was dated to the Early Migration period, i.e. early $5^{\text {th }}$ c. AD (Pieta/Ruttkay 1986; 1997).

\section{RESULTS}

\section{Vrbov, location Vrbovský lesík}

The animal bones and teeth from the riverine unfortified settlement at Vrbov comprise 134 specimens. The material was in a fragmentary state and only a single long bone (metapodium) was preserved completely. Ochre-colored specimens, some with their surfaces covered with a thin layer of brown clay, predominated. The surface bone structures were moderately or strongly eroded.

The taxonomy and anatomy were identified in 87 specimens, i.e. in more than a half of the finds $(65 \%)$. Within the identifiable sample, the presence of cattle (Bos taurus), pig (Sus domesticus) and sheep (Ovis aries) was plausibly evidenced. The occurrence of goats cannot be ruled out, nor can it be confirmed (Ovis/Capra [caprines]).

The species representation was relatively balanced, although slightly more caprines $(42.5 \%$ of NISP) and cattle (39.1\% of NISP) was observed (Tab. 1). Pig remains represented roughly half

\footnotetext{
${ }^{3}$ K. Pieta, personal communication.
} 
Tab. 2. Vrbov-Vrbovský lesík. Assessment of age. Quantified by NISP.

\begin{tabular}{|c|c|c|c|c|c|c|c|}
\hline Vrbov & 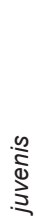 & 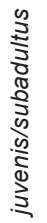 & 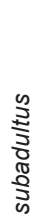 & 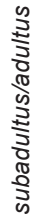 & $\frac{\infty}{\stackrel{2}{3}}$ & 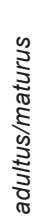 & Total \\
\hline Bos taurus & 1 & 1 & - & 6 & 5 & 1 & 14 \\
\hline cf. Bos taurus & - & - & - & 3 & 1 & - & 4 \\
\hline Ovis aries & - & - & - & 1 & 2 & - & 3 \\
\hline Ovis/Capra & - & - & - & - & 4 & - & 4 \\
\hline cf. Ovis/Capra & - & - & - & - & 1 & - & 1 \\
\hline Sus domesticus & 1 & - & 1 & 2 & 1 & - & 5 \\
\hline Unidentified MM/LM & - & - & - & 3 & - & - & 3 \\
\hline Unidentified LM & - & - & - & 10 & - & - & 10 \\
\hline Total & 2 & 1 & 1 & 25 & 14 & 1 & 44 \\
\hline
\end{tabular}

these numbers (18.4\% of NISP). Wild species were absent, although a single phalanx of Bos displayed a relatively great width and length parameters and robusticity suggesting that it may have come from either a female aurochs (Bos primigenius) or (which seems more likely) large domestic cattle (Bos taurus) - a bull or an ox. Regarding the MNI, remains of at least five individuals in different age categories were found in feature 1/85. In addition to cranial and postcranial bones of the adult sheep older than 3-4 years, bones of at least two calves, aged $0.5-1$ and $1.5-2.5$ years the adult cattle older than 3 years and a juvenile pig aged 5-10 months were recorded.

The dental and skeletal age (Tab. 2) of cattle attested the presence of adults (older than 3-4 years) as well as juvenile individuals $(0.5-1$ year and $1.5-2.5$ years). A variable age at slaughter was recorded for pigs. On the other hand, juvenile individuals were not identified among the caprine finds. All aged specimens had permanent teeth and closed epiphyseal fissures, i.e. were older than 2 years. The whole assemblage reflected only sporadic presence of juvenile animals from all domestic species $(10 \%$ NISP).

The sex and morphometric data from Vrbov are scarce (Tab. 3). A find of a parietal bone fragment with rudimentary horncore's protrusion probably belonged to a female sheep. The withers height of a local sheep individual was calculated $(\mathrm{WRH}=$ $595.61 \mathrm{~mm}$ ) on the basis of the greatest length
(119.6 mm) of a single metacarpus recovered in feature $1 / 85$.

Several anthropogenic changes in the natural shape of bones were identified in the Vrbov assemblage. Skinning of the sheep's body is evidenced by multiple short and shallow surface incisions (from a knife blade?) on a distal epiphysis of a metacarpal bone. The fragmentary character and spiral fracturing observed on several long bones suggest intentional breaking of green bones by people/dogs. Probable carnivore gnawing marks were recorded only rarely $(\mathrm{NISP}=3)$. Contact of animal carcasses with fire of a possible anthropogenic origin was not clearly documented, although variable (dark orange spots) discoloration of the proximal epiphysis of the sheep's metacarpal suggests it. There were no calcined or carbonized bones.

\section{Lazisko, location Zvon}

The analysed assemblage from the hilltop unfortified settlement at Lazisko comprises 214 specimens. The material was in a fragmentary state, lacking any completely preserved long bones. The bones were ochre-coloured. Some had black-andpurple spots of unknown origin on their outer surfaces, perhaps developed during the deposition or post-excavation processing of the material. The surface bone structures were relatively well preserved, with only slight to moderate erosion evidenced.

The taxonomic and skeletal element identification was possible in 160 specimens, i.e. in the majority of finds (75.5\%). The remainder was assigned to the groups by size (Tab. 4). Horse (Equus caballus), cattle (Bos taurus), pig (Sus domesticus) and sheep (Ovis aries) were plausibly identified. Similarly, to Vrbov, goat bones were not confirmed and the majority of small ruminants were classified as caprines (Ovis/Capra). As for the wild fauna, an isolated canine of a brown bear (Ursus arctos), originally registered as a small find (DP 11/89; Fig. 2), was identified. The occurrence of gnawing marks made by a medium-sized carnivore indicated the presence of domestic dogs running loose in the Lazisko settlement. Counting the MNI for sounding 1-position 11 suggested the presence of at least six individuals including three cattle, two caprines and one pig.

Among domestic animal remains (NISP $=163$ ), cattle predominated (68.7\%). Remains of caprines were relatively common $(25.2 \%)$, but the bones of pig $(4.3 \%)$ and horse $(1.8 \%)$ occurred only sporadically. The representation of wild species was again 
Tab. 3. Osteometrical data of the finds from Vrbov and Lazisko.

\begin{tabular}{|c|c|c|c|c|}
\hline Site & Skeletal element & Side & Measurement(s) & Notes \\
\hline \multicolumn{5}{|c|}{ Cattle (Bos taurus) } \\
\hline Vrbov $7 / 13$ & molar 1 superior & $\sin$ & $L=21.23, B=19.78$ & - \\
\hline Vrbov $7 / 14$ & molar 1 superior & $\sin$ & $L=24.67, B=10.99$ & - \\
\hline Vrbov $6 / 4$ & molar 3 inferior & $\sin$ & $L=(33.98), B=14.91$ & - \\
\hline Lazisko 4/5 & molar 3 inferior & $\sin$ & $L=34.10, B=13.26$ & - \\
\hline Vrbov $11 / 8$ & mandibula & $d x$ & AvdD9 $=37.40, \mathrm{~L}-\mathrm{M} 1=19.58, \mathrm{~B}-\mathrm{M} 1=13.19, \mathrm{~L}-\mathrm{M} 2=23.46, \mathrm{~B}-\mathrm{M} 2=13.45$ & - \\
\hline Lazisko $3 / 3$ & mandibula & $d x$ & L-M3 = 30.59, B-M3 = 11.17 & - \\
\hline Lazisko 8/6 & radius & $d x$ & $\mathrm{Bp}=76.90, \mathrm{BFp}=70.43$ & - \\
\hline Lazisko $7 / 3$ & pelvis & $d x$ & $L A=51.68$ & - \\
\hline Lazisko 6/12 & tibia & $d x$ & $\mathrm{Bp}=74.08$ & - \\
\hline Lazisko 6/32 & tibia & $d x$ & $\mathrm{Bd}=54.88, \mathrm{Td}=39.02$ & - \\
\hline Lazisko $9 / 2$ & tibia & $\sin$ & $\mathrm{Bd}=50.50$ & - \\
\hline Vrbov $7 / 5$ & talus & $d x$ & $\mathrm{GLI}=62.50, \mathrm{GLm}=(55.56)$ & - \\
\hline Lazisko 6/15a & talus & $\sin$ & $\mathrm{GLI}=57.6, \mathrm{DI}=31.38, \mathrm{GLm}=53.61, \mathrm{Bd}=36.52$ & individual $\mathrm{A}$ \\
\hline Lazisko 6/15b & talus & $d x$ & $\mathrm{GLI}=56.07, \mathrm{DI}=31.26, \mathrm{GLm}=51.72, \mathrm{Dm}=30.90, \mathrm{Bd}=36.67$ & individual $\mathrm{A}$ \\
\hline Lazisko 6/20 & calcaneus & $d x$ & $\mathrm{~GB}=35.6$ & - \\
\hline Lazisko 7/1 & calcaneus & $\sin$ & $\mathrm{GB}=(42.48)$ & - \\
\hline Lazisko 6/21 & metacarpus & $\sin$ & $\mathrm{Bp}=44.10$ & - \\
\hline Lazisko 2/4 & metatarsus & $d x$ & $\mathrm{Dd}=19.9$ & - \\
\hline Lazisko $5 / 3$ & metatarsus & $d x$ & $\mathrm{Bd}=44.85, \mathrm{Dd}=20.51$ & - \\
\hline Lazisko 8/5 & metatarsus & $\sin$ & $\mathrm{Bd}=49.52$ & - \\
\hline Vrbov $7 / 6$ & phalanx 1 , anterior & $?$ & $\mathrm{SD}=23.56, \mathrm{GLPe}=(52.95), \mathrm{Bd}=27.42$ & - \\
\hline Lazisko 6/19 & phalanx 1 , posterior & $?$ & $\mathrm{GLpe}=55.62, \mathrm{Bp}=(23.70), \mathrm{SD}=19.18, \mathrm{Bd}=23.63$ & - \\
\hline Lazisko $7 / 4$ & phalanx 1, posterior & $?$ & $\mathrm{GLPe}=(54.88), \mathrm{Bp}=26.30, \mathrm{SD}=21.28, \mathrm{Bd}=26.00$ & - \\
\hline Lazisko 6/17 & phalanx 1 & $?$ & GLpe $=48.72, B p=24.31, S D=20.32$ & - \\
\hline Lazisko 6/18 & phalanx 1 & $?$ & $\mathrm{GLpe}=52.17, \mathrm{Bp}=(26.03), \mathrm{SD}=21.26, \mathrm{Bd}=23.63$ & - \\
\hline Vrbov $92 / 1$ & phalanx 2 anterior & $?$ & $\mathrm{GL}=41.39$ & Bos sp. \\
\hline Vrbov $7 / 7$ & phalanx 2 & $?$ & $\mathrm{Bp}=(27.91), \mathrm{SD}=22.79, \mathrm{Bd}=(21.69)$ & - \\
\hline Lazisko 6/16 & phalanx 3 & $?$ & $L d=(51.24), M B S=(24.70)$ & - \\
\hline \multicolumn{5}{|c|}{ Pig (Sus domesticus) } \\
\hline Vrbov $7 / 2$ & molar 2 superior & $d x$ & $\mathrm{~L}-\mathrm{M} 2=16.24, \mathrm{~B}-\mathrm{M} 2=12.59$ & - \\
\hline Vrbov $155 / 1$ & mandibula & $d x$ & L-M2 = 20.26, B-M2 = 13.61, L-M3 = 34.02, B-M3 = 15.73 & - \\
\hline Lazisko $7 / 6$ & scapula & $\mathrm{dx}$ & SLC $=20.67$ & - \\
\hline Vrbov $7 / 1$ & talus & $\sin$ & $\mathrm{GLI}=37.28, \mathrm{Gm}=34.64$ & - \\
\hline Vrbov $7 / 4$ & patella & $\sin$ & $\mathrm{GL}=34.67, \mathrm{~GB}=18.23$ & - \\
\hline \multicolumn{5}{|c|}{ Sheep (Ovis aries) } \\
\hline Lazisko 8/30 & radius & $d x$ & $\mathrm{Bp}=(30.86)$ & - \\
\hline Lazisko $6 / 1$ & tibia & $d x$ & $\mathrm{Bp}=(40.24)$ & - \\
\hline Vrbov $9 / 1$ & metacarpus & $d x$ & $\mathrm{GL}=119.6, \mathrm{Bp}=21.87, \mathrm{SD}=12.26, \mathrm{Bd}=23.84, \mathrm{Dd}=8.59$ & - \\
\hline Vrbov $9 / 2$ & metacarpus & $\sin$ & $\mathrm{GL}=119.7, \mathrm{Bp}=21.24, \mathrm{SD}=12.45, \mathrm{Bd}=23.21, \mathrm{Dd}=8.59$ & - \\
\hline
\end{tabular}


Tab. 3. Continuation.

\begin{tabular}{|c|c|c|c|c|}
\hline Site & Skeletal element & Side & Measurement(s) & Notes \\
\hline \multicolumn{5}{|c|}{ Caprines (Ovis/Capra) } \\
\hline Vrbov 8/12 & mandibula & $\sin$ & AvdD9 $=25.70$ & - \\
\hline Lazisko 6/5 & mandibula & $\sin$ & L-M1 = 15.36, B-M1 = 7.22 & $\begin{array}{l}\text { juvenile } \\
\text { (6-12 months) }\end{array}$ \\
\hline Vrbov 8/14 & molar 1-2 inferior & $d x$ & L-M1 = 13.14, B-M1 = 7.57, L-M2 = 15.89, B-M2 = 8.72 & - \\
\hline Lazisko 6/6 & molar 1 inferior & $d x$ & L-M1 $=15.19, \mathrm{~B}-\mathrm{M} 1=6.99$ & - \\
\hline Lazisko 6/7 & molar 1 inferior & $d x$ & L-M1 = 12.83, B-M1 = 7.28 & - \\
\hline Lazisko 6/3 & pelvis & $d x$ & $L A=28.43$ & - \\
\hline Lazisko 6/4 & tibia & ? & $\mathrm{SD}=(12.30)$ & - \\
\hline Lazisko $7 / 10$ & metacarpus & $d x$ & $\mathrm{Bp}=22.20$ & - \\
\hline \multicolumn{5}{|c|}{ Horse (Equus caballus) } \\
\hline Lazisko 6/29 & radius & $d x$ & $\mathrm{Bd}=72.34, \mathrm{BFd}=59.56$ & - \\
\hline Lazisko $8 / 26$ & pelvis & $\sin$ & $\mathrm{LA}=(59.07)$ & - \\
\hline \multicolumn{5}{|c|}{ Brown bear (Ursus arctos) } \\
\hline Lazisko $11 / 89$ & caninus superior & $\sin$ & $\begin{array}{l}\mathrm{GL}=88.80, \text { smallest diameter of the crown base }=20.15 \text {, largest diameter } \\
\text { of the crown base }=15.28\end{array}$ & - \\
\hline
\end{tabular}

The table provides a list of measurements in millimetres taken according to the method of A. von den Driesch (1976). The measurements are arranged after species with indication of site and specimen number. The abbreviations or measurement numbers follow A. von den Driesch (1976), i.e. A - acetabulum; AvdD - measurement number after Angela von den Driesch; B - breadth; D - depth; Dia - diameter; G - greatest; L - length; 1 - lateral; M - molar; $\mathrm{m}$ - medial; $\mathrm{S}$ - smallest; $\mathrm{d}$ - distal; $\mathrm{p}$ - proximal. The side of the bone is left (sin), right (dx) or unknown. The values in the brackets indicate approximative measures.

Tab. 4. Lazisko-Zvon. Taxonomic and anatomic determination. Quantified by NISP.

\begin{tabular}{|c|c|c|c|c|c|c|c|c|c|c|c|c|c|c|c|c|c|c|c|c|c|c|c|}
\hline Lazisko & 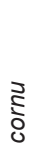 & 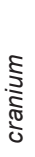 & 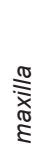 & $\begin{array}{l}\frac{\pi}{3} \\
\frac{0}{\delta} \\
\frac{\pi}{\pi} \\
\text { है }\end{array}$ & $\frac{\sum_{0}^{\infty}}{0}$ & $\underset{\underset{\pi}{\mathbb{T}}}{\stackrel{\mathscr{D}}{\mathbf{T}}}$ & $\frac{\pi}{\frac{\pi}{0}}$ & $\begin{array}{l}\frac{\pi}{5} \\
0 \\
0\end{array}$ & $\begin{array}{l}\frac{\pi}{3} \\
\frac{0}{\mathbb{d}} \\
\mathbb{\infty}\end{array}$ & 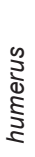 & 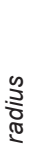 & $\stackrel{\text { D) }}{\stackrel{5}{5}}$ & $\frac{\infty}{\sum_{0}^{\infty}}$ & $\underset{\downarrow}{\frac{\delta}{d}}$ & $\underset{2}{\frac{\pi}{2}}$ & 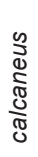 & $\frac{\infty}{\sqrt[D]{d}}$ & 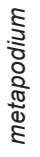 & 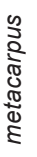 & 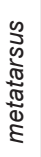 & $\frac{\frac{x}{d}}{\frac{d}{d}}$ & $?$ & Total \\
\hline Bos taurus & 1 & - & 1 & 9 & 8 & 1 & - & - & 2 & - & 2 & 2 & 3 & 3 & 7 & 2 & 2 & 1 & 4 & 5 & 6 & - & 59 \\
\hline cf. Bos taurus & - & 1 & 1 & 2 & - & - & 13 & 21 & 1 & 2 & - & 1 & 1 & 2 & 2 & - & - & 1 & 1 & 1 & - & 3 & 53 \\
\hline Ovis aries & - & - & - & - & - & - & - & - & - & - & - & - & - & - & 1 & - & - & - & - & - & - & - & 1 \\
\hline Ovis/Capra & - & - & 2 & 4 & 18 & 1 & - & - & - & - & - & - & 3 & - & 4 & - & - & - & 2 & 1 & - & - & 35 \\
\hline cf. Ovis/Capra & - & - & - & - & - & - & - & 4 & - & 1 & - & - & - & - & - & - & - & - & - & - & - & - & 5 \\
\hline Sus domesticus & - & - & - & 1 & 4 & - & - & - & 1 & - & - & - & - & - & - & - & - & - & - & - & 1 & - & 7 \\
\hline Equus caballus & - & - & - & - & - & - & - & - & - & - & 1 & - & 1 & - & - & - & - & - & - & - & 1 & - & 3 \\
\hline Ursus arctos & - & - & - & - & 1 & - & - & - & - & - & - & - & - & - & - & - & - & - & - & - & - & - & 1 \\
\hline Bos/Equus & - & - & - & - & - & - & - & - & 1 & - & - & - & - & - & - & - & - & - & - & - & - & - & 1 \\
\hline Unidentified MM & - & - & - & - & - & - & - & - & - & 1 & - & - & - & - & - & - & - & - & - & - & - & 1 & 2 \\
\hline Unidentified MM/LM & - & - & - & - & - & - & 1 & 6 & - & - & - & - & - & - & - & - & - & - & - & - & - & 9 & 16 \\
\hline Unidentified LM & - & - & - & - & - & - & 1 & 6 & 1 & - & - & - & - & - & - & - & - & - & - & - & - & 23 & 31 \\
\hline Total & 1 & 1 & 4 & 16 & 31 & 2 & 15 & 37 & 6 & 4 & 3 & 3 & 8 & 5 & 14 & 2 & 2 & 2 & 7 & 7 & 8 & 36 & 214 \\
\hline
\end{tabular}




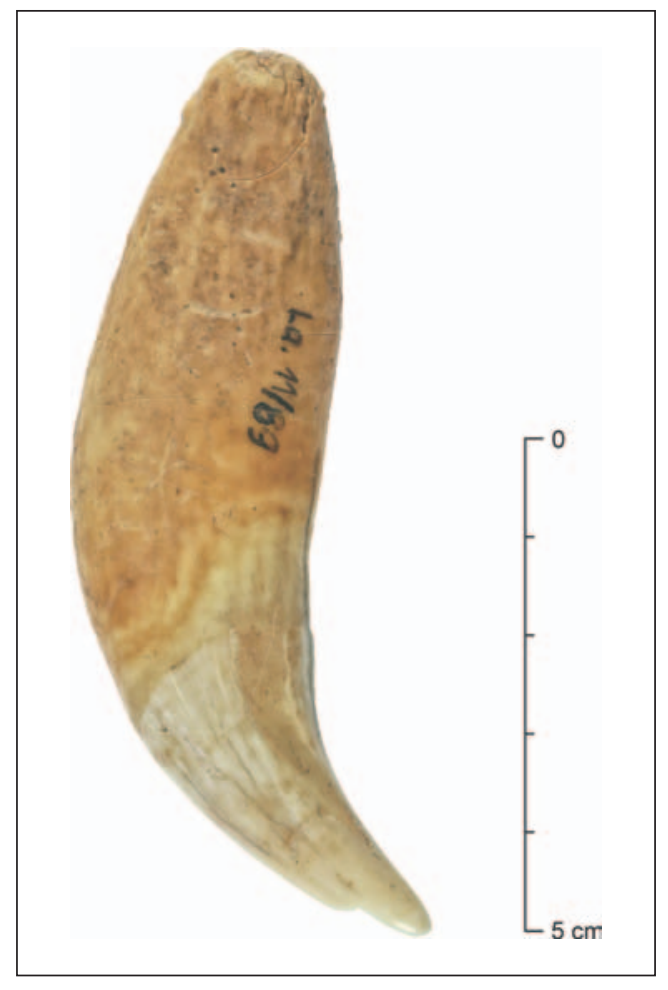

Fig. 2. Lazisko-Zvon. The brown bear (Ursus arctos) canine tooth. Unworked (photo by P. Červeň).

negligible. The horse remains (Fig. 3) belonged to an adult (acetabulum, radius) and a subadult individual (phalanx 1). In total, 139 specimens $(65.6 \%)$ could be assigned to age categories (Tab. 5). The juvenile and subadult individuals (0.5-2.5 years) represented $19.4 \%$ of the identified specimens, subadult/adult $61.9 \%$ and adult animals (3-4 years and more) represented $18.7 \%$ of the total. In cattle, the juvenile and subadult individuals account for about $20 \%$ (NISP $=50$ ) of the assemblage while caprines account for $31.6 \%$ (NISP $=19$ ) of the total. As mentioned above, a horse is most likely represented by two individuals - the subadult one, at 1.5 to 2.5 years and the adult, older than 3.5 years. Diverse age was recorded for cattle: juvenile (aged 6-12 months and 12-24 months), subadult (1.5-3.5 years old) and adult individuals (3.5-4 years old). In caprines, individuals of 6-12 month, $1.5-2$ years, $2-2.5$ years, 3-4 years and older were present. The sheep were killed as a young adult (by the $1.5-2^{\text {nd }}$ year) and adults (at $3^{\text {rd }}-4^{\text {th }}$ year). Pig remains from individuals both younger and older than one year were recorded. Unfortunately, the sex of these animals could not be determined. Morphometric analysis provided only few measurements (Tab. 3) and the absence of complete long bones or skulls remains did not allow withers height calculation or morphological assessments.

The processing of animal carcasses at the studied site is indicated by the variety of cranial and postcranial skeletal elements in the assemblage, including meatless bones such as the skull, horncores, metapodials, or phalanges. Butchered remains were recorded for all the domestic species, although the overall low number of finds for pigs and horses limited analysis of butchery patterns. A number of

Tab. 5. Lazisko-Zvon. Assessment of age. Quantified by NISP.

\begin{tabular}{|c|c|c|c|c|c|c|c|c|c|c|c|}
\hline Lazisko & $\begin{array}{l}\frac{\infty}{\delta} \\
\stackrel{D}{J}\end{array}$ & 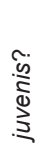 & 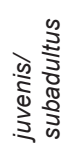 & 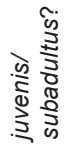 & 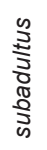 & 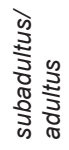 & 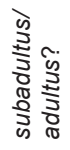 & $\frac{\stackrel{\infty}{3}}{\stackrel{D}{T}}$ & $\frac{\tilde{D}}{3}$ & $?$ & Total \\
\hline Bos taurus & 4 & - & 4 & - & 2 & 11 & 9 & 12 & 8 & 3 & 53 \\
\hline cf. Bos taurus & - & - & 3 & 4 & - & 7 & 29 & - & - & 7 & 50 \\
\hline Ovis aries & - & - & - & - & - & - & - & 1 & - & - & 1 \\
\hline Ovis/Capra & 1 & - & 1 & 3 & 1 & - & 8 & 3 & 1 & 2 & 20 \\
\hline cf. Ovis/Capra & - & - & - & - & - & - & 2 & - & - & 3 & 5 \\
\hline Sus domesticus & - & 1 & - & - & - & 1 & 1 & - & - & 1 & 4 \\
\hline Equus caballus & - & - & - & - & 1 & - & 1 & 1 & - & - & 3 \\
\hline Ursus arctos & - & - & - & - & - & 1 & - & - & - & - & 1 \\
\hline Bos/Equus & - & - & - & - & - & - & 1 & - & - & - & 1 \\
\hline Unidentified MM & - & 2 & - & - & - & - & - & - & - & - & 2 \\
\hline Unidentified MM/LM & - & - & - & - & - & - & - & - & - & 16 & 16 \\
\hline Unidentified LM & - & - & - & - & - & 1 & 14 & - & - & 16 & 31 \\
\hline Total & 5 & 3 & 8 & 7 & 4 & 21 & 65 & 17 & 9 & 48 & 187 \\
\hline
\end{tabular}




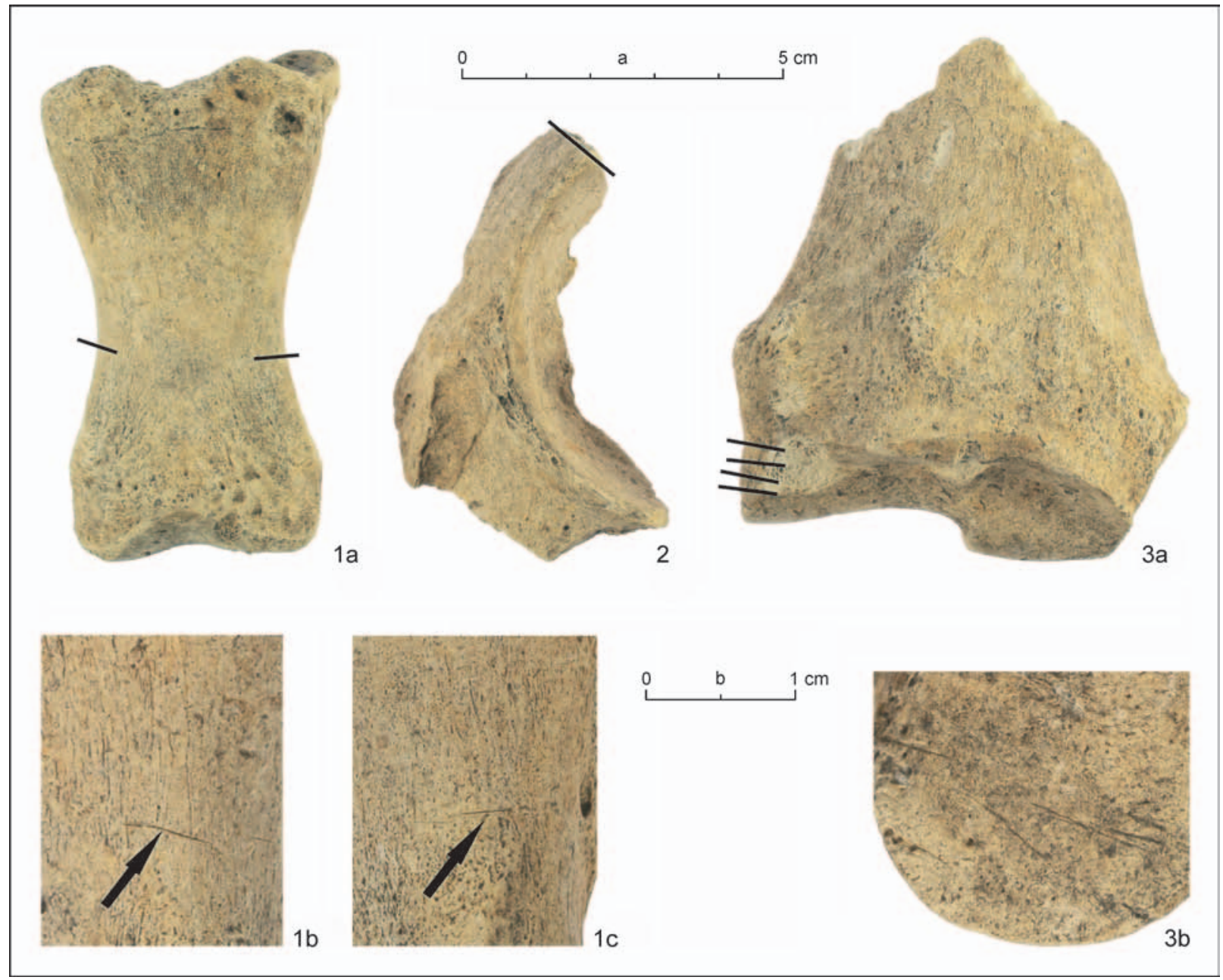

Fig. 3. Lazisko-Zvon. The horse remains (Equus caballus) with location of cut and chop marks. 1 - first phalanx of a subadult individual (note the fusing proximal epiphysis), dorsal view (b, $\mathrm{c}$ - transversal, skinning marks located in the middle of diaphysis, lateral and medial view); 2 - fragment of the left acetabulum with chop marks; 3 - distal part of the right radius of an adult individual, dorsal view ( $b-$ multiple transversal cut marks in epiphysis, lateral view). Scale: $a-1 a$, $2,3 a ; b-1 b, 1 c, 3 b$ (photo by P. Červeň).

spiral fractures on green bone evidence butchery activities by the population. Beside the examples of shallow and short cut marks caused by the puncture and pulling a small sharp blade along the bone surface during hide removal, there were also marks that attest the processing of the animals' carcasses (e.g. dismembering of joints, tendon and meat removal, etc.). A few isolated cases of short and shallow cut marks situated laterally or medially in the middle of the phalanx diaphysis were present in a horse (Fig. 3: 1b, c). There were also marks from cuts and chop marks from breaking the bones (especially ribs, lower mandible, and scapula) into portions of different size (pot/grill-sizing or for the preparation of particular dishes; Fig. 3: 2, 3).

Burnt or partially burnt bones occurred sporadically (NISP $=7$ ). Their colour spectrum runs from reddish brown to brown-black suggested the bone element came into contact with an open fire/ heat, with a temperature ranging between $250{ }^{\circ} \mathrm{C}$ to $550{ }^{\circ} \mathrm{C}$. The marks were found on a few cattle bone specimens like a humerus and metapodium from sounding III and a distal tibia from sounding IV. Intensive burning (carbonization or calcination; black-brown-grey to white coloration) was registered in two unidentified long bone fragments from an unidentified large mammal in sounding 1 . Traces of carnivore gnawing were rare (NISP $=2)$, indicating that dogs or other scavengers had only limited access to the kitchen waste in the studied (residential?) settlement area.

A solitary finds of a bear upper canine (caninus superior) was unworked. A weak sign of abrasion on the enamel part of the crown, developed during 
the life of the animal, suggested that the animal was a young adult when it died. Half of the tooth's tip was freshly broken off, perhaps during postexcavation processing or handling.

Non-anthropogenic modifications are represented by the polishing and pitting in the first phalanx of a pig. This bone most probably represents kitchen leftovers digested by dogs.

The assemblage also contained a pathological specimen, probably of traumatic origin or from a long-term tethering of the animal. A longitudinal depression with round edges was observed below the proximal epiphysis, on the dorsal side of a caprine metacarpus.

\section{DISCUSSION}

\section{Meat Diet}

The refuse from the North Carpathian group settlements at Vrbov and Lazisko is dominated by bones of domestic animals. The analysis clearly attested consumption of beef, lamb/mutton and pork at both sites. The fragmentary character of bones and butchery marks from the perimortal period support this assumption. The relative quantitative results suggest that during the Late Roman and Early Migration periods the North Carpathians preferred beef and lamb/mutton in their diet. It very likely that people also consumed horse meat, at least at Lazisko. The paucity of sexing and ageing data, however, provided only preliminary information on kinds of meat cuts that were preferred. In Vrbov, consumption of pork from a male individual of 1-2 years old was attested. The absence of meat from juvenile and subadult caprines was observed at this site as well, but it is questionable whether this absence reflects 'meat preferences' in caprine herd management (see below) or the overall small number of finds analysed (age category was identified for eight specimens only). Although beef came mainly from adult cattle, consumption of veal was documented at both sites, for instance at Vrbov, very young animals were slaughtered before and shortly after their first winter (at the age of 6-12 months and 1.5 year). At Lazisko, the age estimation clearly evidenced killing of cattle, sheep, pig and horses in various age categories - as juveniles (6-12 months), subadults (1.5 to 2.5 years), young adults (at $3^{\text {rd }}$ or $4^{\text {th }}$ year) or as even older adults (after the $3^{\text {rd }}$ or $4^{\text {th }}$ year). The veal, lamb and pork from young animals was definitely a part of the meat dishes at Lazisko.

The butchering pattern included a number of spiral fractures, resulting most probably from breaking fresh, green bone (Lyman 1994, 319, fig. 8: 4). This suggests there was deliberate marrow exploitation at both settlements. A number of cut marks made by a knife, observed mainly in Lazisko, attested the processing of animal bodies including skinning, joint disarticulation, portioning (e.g. shoulder blade, ribs) or defleshing meat from the bone. The initial stages of carcass processing are indicated by the occurrence of meatless parts of the cranial region (e.g. cattle and sheep horn cores) and postcranial skeletal elements (e.g. caudal vertebrae, phalanges) in the assemblages. Except for the brown bear upper canine, all identified species were kept on or brought live to the sites. Aside from the meat and marrow, the horn, hide, sinew, viscera or blood were available for the local kitchen and craft activities. Examples of cut marks on non-meaty skin-covered bone surfaces (e.g. metapodials, phalanges) clearly suggest skinning activities (horse, cattle, caprines).

The absence of wild species remains in the studied assemblages indicate that the subsistence of the North Carpathian group was broadly dependent on agriculture. Wild mammals ${ }^{4}$ represented just the occasional (seasonal?) enrichment of the diet (Pieta 1991; Tunia 1989). Although the number of studied finds was relatively small and non-representative, the achieved results probably reflect the presence of simple meat dishes consumed in the highlands and the population's dependence on domestic animal production. Interestingly, despite their different geographic settings, the Lazisko (hilltop) and Vrbov (river terrace), beef and mutton/lamb were preferred in both communities. In Liptov, such a dietary pattern is characteristic for nearly all analysed Iron Age and Roman period settlements from the Púchov Cultural milieu (Fig. 4). Some recent archaeozoological data from the protohistoric settlements at Likavka-Predné hony and Ploštín-Pod Rohačkou fits fully the 'mountain diet' (Benediková et al. 2019; 2020). It must be added, however, that beef and lamb/mutton was also preferred at some Late Roman period settlements situated in the lowlands of southwestern Slovakia (e.g. Vel'ký Meder or Most pri Bratislave; Bielichová 2019a). Here, in the region of Bratislava, the growing popularity of pork towards the $3^{\text {rd }}$ and $4^{\text {th }} \mathrm{c}$. $\mathrm{AD}$ was recorded and interpreted as a consequence of a more stable and rich economy, general population

\footnotetext{
4 This assumption refers only to wild mammals. Fish, wild/domestic birds and other microfauna cannot be studied on the basis of yet available archaeozoological data from Slovakia.
} 


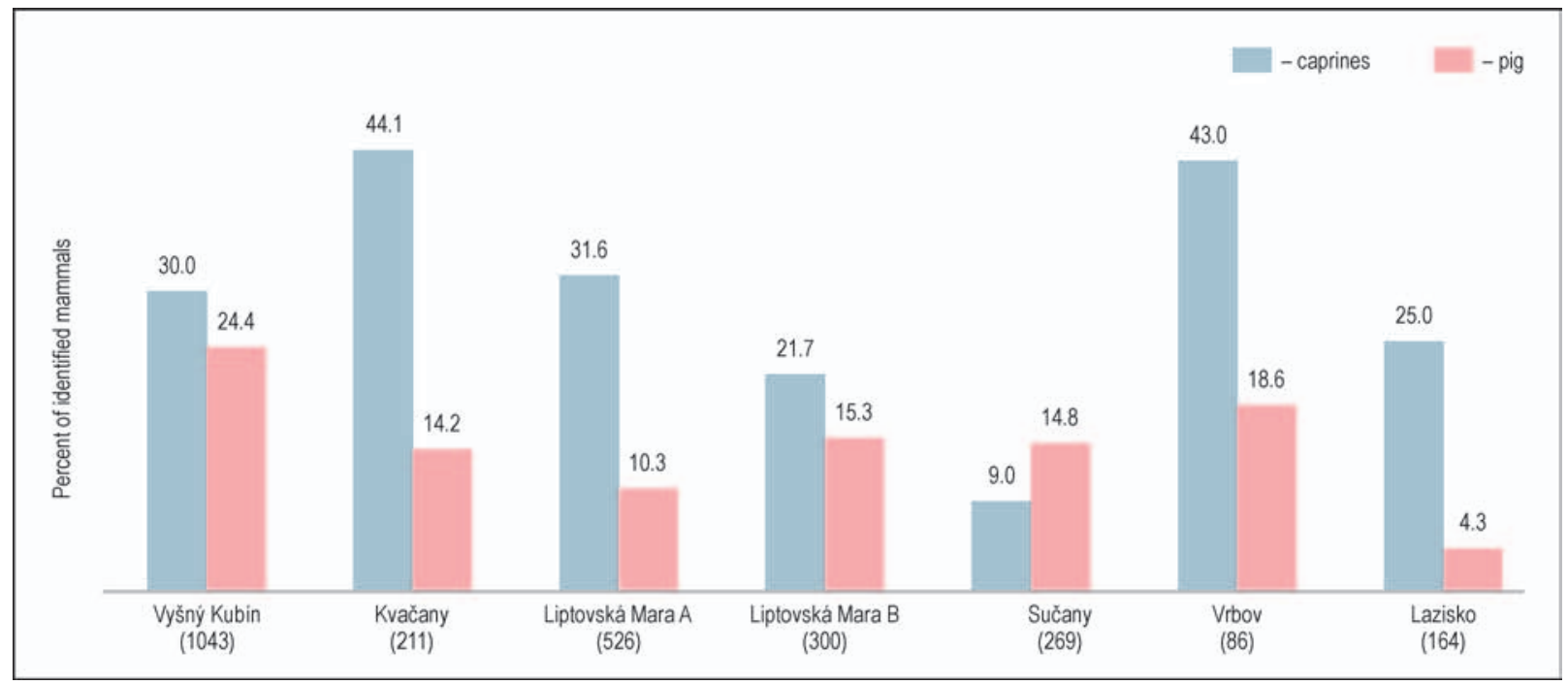

Fig. 4. The representation of caprines and pig remains at the Púchov culture (NISP data from Ambros 1978; Pieta 1982) and the North Carpathian group settlements from northern Slovakia. Hallstat period: Vyšný Kubín; La Tène period: Kvačany, Liptovská Mara I; Early Roman period: Liptovská Mara II, Sučany; Late Roman/Early Migration period: Vrbov, Lazisko.

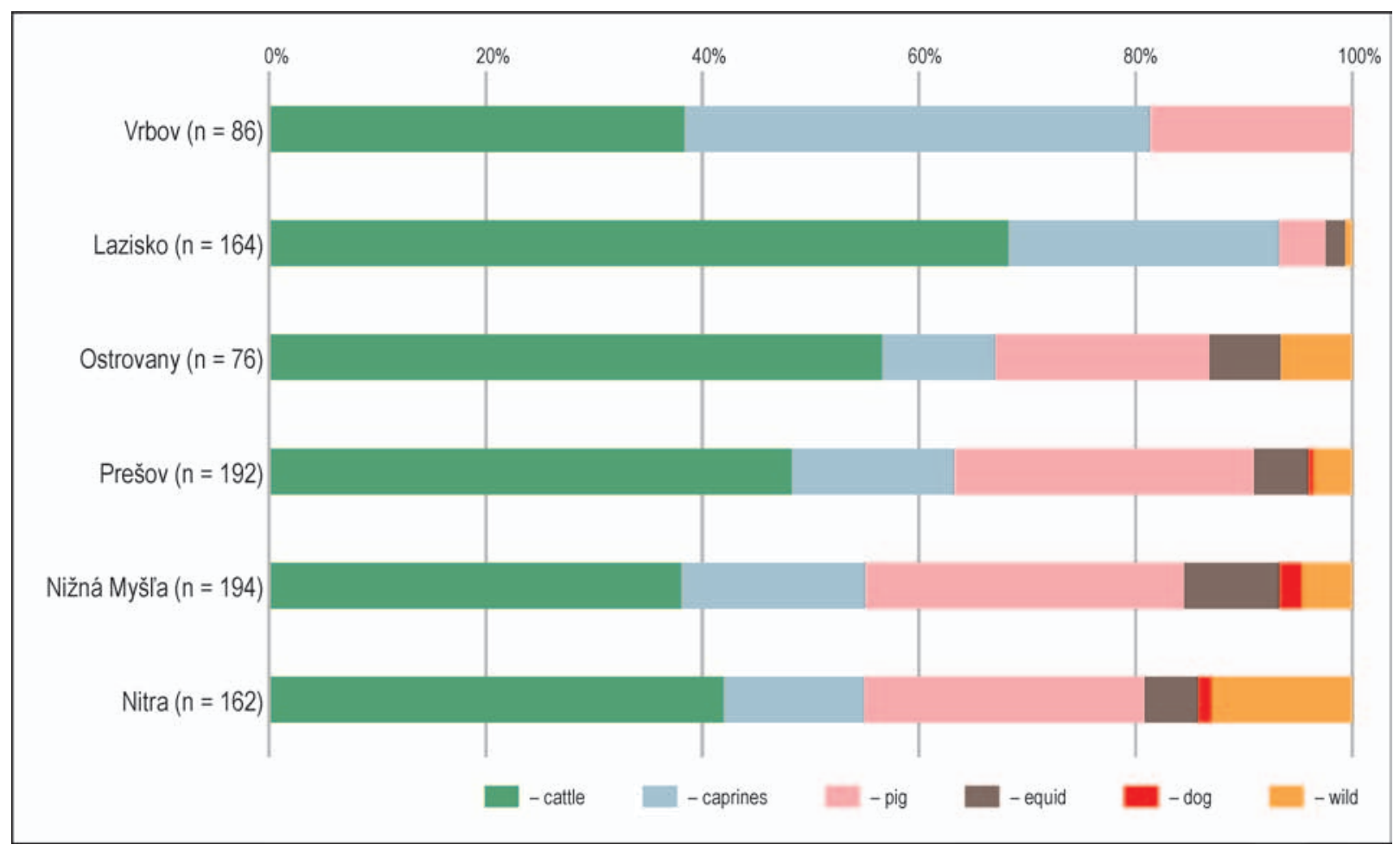

Fig. 5. The representation of domestic and wild mammals at the settlements of the Late Roman and Early Migration period in Slovakia (NISP data from Ambros 1960; 1961; 1962; 1986; Rajtová 1964; 1991).

increase or adaptation of Roman culinary traditions (Bielichová 2019a, 83). Occasional hippophagy also occurred in Quadi settlements (e.g. Bielichová 2019, 82; Fabiš/Bielichová 2014).

The faunal assemblages of contemporary settlements in Prešov, Nižná Myšla or Ostrovany, representing the eastern limit of the North Carpathian group settlements, display a very similar dietary pattern for meat with a preference for beef and pork and variable meat types including goat, chicken, red deer, beaver, donkey and fresh-water mussels (Fig. 5; Ambros 1961; Rajtová 
1964; 1991). The only analysed early migration period settlement faunal assemblage from the southwest - Nitra-Párovské Háje - also comprised a rich species spectrum including wild boar, wolf, roe deer, hare, fish, and chicken with eggs (Ambros 1986). The game at these settlements comprised $3.6 \%$ at Prešov-Pavlovičovo námestie to $13.3 \%$ at Nitra-Párovské Háje out of the total of identifiable bone specimens. ${ }^{5}$

Interestingly, a solitary find of a brown bear molar was also reported from Ostrovany (Rajtová 1964, 269), but as in Lazisko, its archaeological context remained questionable. This tooth was also not worked (e.g. no perforation or modification of the root) or evidence of use (e.g. polish), so it is hard to determine their use or importance for people at the settlement. A study of brown bear remains including skull fragments, mandibles, carpalia and phalanges from the central La Tène and Early Roman settlement at Liptovská Sielnica-Liptovská Mara however, suggest that rather than specialized hunting for meat and/or skin, bears may have been killed occasionally as a consequence of their attacks on domestic livestock (Chrószcz et al. 2014). Keeping teeth as hunting trophies or amulets, evidenced for instance by a perforated tooth from the Late La Tène settlement at Liptovská Mara (Pieta 1982, pl. XIII: 31), is a possible explanation for the presence of isolated brown bear teeth from Lazisko and Ostrovany, although other interpretations cannot be excluded (e.g. Grimm 2013; Oehrl 2013).

\section{Animal Husbandry}

Based on the variety of anatomical parts and a number of juvenile individuals, the meat eaten at Vrbov and Lazisko originated from locally reared cattle and caprines. Most possibly, this subsistence pattern also applied to horses and pigs. The proximity of water and grazing lands, typical of both sites, must have been a determining factor for the North Carpathian people's animal production. From the spring to the autumn, the surrounding highlands offered rich pastures, but the harsh times of winter may have forced people to provide additional fodder and shelter for the animals. Finds of the reaping tools including short scythes and bow-shaped massive knives for pruning work from these sites can reflect such activities (Pieta 1991, 383). North Carpathian group find assemblages also contain a significant number of artefacts of foreign origin including a Mediter- ranean conch-shell (Murex trunculus), also found on contemporary Pannonian sites, was found at Vrbov (Pieta 1991, 378, 379, fig. 2: 26; Soják 2015, 132, fig. 184: 1). Nevertheless, the low number of animal bones do not permit comments on potential supplying of domestic animals from other regions, but it is important to draw attention to the finds from the eastern limit zone, where such imports were observed. In Ostrovany, besides the Late Roman African pottery lamps and the amphorae, remains of originally African species such as donkey (Equus asinus), provided a clear indication of contacts with the Roman provinces (Rajtová 1964).

As evidenced by the relative representation of taxa, local husbandry was focused on cattle and caprines (sheep identified, goat presumed). The rare osteometric data suggested that cattle and sheep were small to middle-sized animals, very similar to the stock kept by the Celtic and Germanic tribes previously settled in the Central European region (e.g. Benecke 1994; Bielichová 2019a, 2019b; Bökönyi 1974; Fabiš 2000; 2003). The size of sheep was evidenced by the calculated withers height of a single sheep from Vrbov $(60 \mathrm{~cm})$ which fully corresponds to the average values given for the Iron Age and Migration period sheep (Bielichová 2019a, 95; 2019b; 224; Bökönyi 1974, 177-181). For example, the average La Tène sheep from the settlement in Nitra-Šindolka was $60.2 \mathrm{~cm}$ at the withers (Fabiš 2000, 302), while Germanic sheep kept at Nitra-Chrenová were significantly larger $(69.65 \mathrm{~cm}$ on the average) and probably represent one of the improved Pannonian Roman 'breeds' (Fabiš 2003, 109). In Hungary, sheep with withers heights below $60 \mathrm{~cm}$ were considered local (Bökönyi 1974, 178). In general, the Roman and Migration period sites of Central Europe display great variability and regional differences in the size of sheep (ranging from 50.4 at Neuss to $85.4 \mathrm{~cm}$ at the Roman site of Tác-Gorsium; Benecke 1994, 375, tab. 45). At Przeworsk Culture settlements, sheep were a bit larger than the individual from Vrbov with withers heights of ca. 63-64 cm (Benecke 1994, 169).

As for cattle, the range of measurements recorded on skeletal elements from Vrbov and Lazisko faunal assemblages does not exceed the variation reported at other Iron Age and Roman period settlements (see Benecke 1994; Bielichová 2019a; 2019b; Bökönyi 1974) and indicates that small and short-horned (?) animals were kept. On the other hand, a few Late Roman specimens from Ostrovany suggested the presence of an extraordinarily

\footnotetext{
5 In Nitra, the percentage of wild mammals is increased due to counting in the bones from partial roe deer and hare skeletons (Ambros 1986).
} 
large individual ${ }^{6}$ and/or the possible coexistence of two cattle 'breeds' - one smaller than and the other larger than modern cattle (Rajtová 1964, 266, 267, pl. III-V). In comparison, osteometric data from the site materials analysed for this paper correspond to the smaller type of cattle. The cattle from the Quadi settlements in southwestern Slovakia had an average withers height $117 \mathrm{~cm}$ with slightly larger talus than those recorded at Vrbov and Lazisko (compare Tab. 3 to Bielichová 2019a, 94, tab. 11). This would suggest that the 'mountain cattle' were smaller than those from lowlands adjacent to the Danube provinces. The information on cattle kept in the mountains during the Iron Age and Early Roman period from Liptovská Mara (WRH of 102.3-113.4 cm) supports this supposition. In other parts of Europe, the average Germanic cattle withers height was $109 \mathrm{~cm}$ while that of Romanprovincial cattle was $124 \mathrm{~cm}$ (Benecke 1994, 167).

Regarding local horses, their size may be assessed on the basis of their overall morphology and a couple of recorded measurements. The breadth of the distal radius from Lazisko $(\mathrm{Bd}=72.34$ and $\mathrm{BFd}=59.56 \mathrm{~mm}$ ) was comparable, although not exceeding those from a reference early medieval stallion $(\mathrm{Bd}=74.01 ; \mathrm{BFd}=61.25 \mathrm{~mm} ; \mathrm{WRH}=$ $132.5 \mathrm{~cm}){ }^{7}$ The late/final Roman period horse from the Quadi settlement at Nitra-Chrenová displayed slightly larger radius measurements $(\mathrm{Bd}=77.2$; $\mathrm{BFd}=65.7 \mathrm{~mm}$; Fabis 2003,126$)$ than those measured on the specimen from Lazisko. There is also a measurable horse metatarsus from Ostrovany from a small-sized horse with slender limbs (Rajtová 1964, 265, 266, pl. II). In Europe, the withers height of Germanic horses ranged between 113 and $147 \mathrm{~cm}$ (Benecke 1994, 171). For instance, finds from Liptovská Mara showed that during the La Tène and Early Roman period small- to middle-sized horses with wither heights between 126 and $138 \mathrm{~cm}$ were kept (Bielichová 2019b, 226). A comparison with the reference stallion indicated that the horses from Lazisko probably did not exceed the range of small-sized horses and might have been similar to the recent Hucul or Carpathian pony with an average height of $136 \mathrm{~cm}$. This breed, native to the Carpathian Mountains, was originally used as a draft animal for pulling timber in forests, a pack animal, and riding horse on rough terrain or inaccessible mountainous routes. ${ }^{8}$
And what was the focus of animal husbandry among the North Carpathian group people? The obtained ageing data suggest that cattle and caprines were species of combined utility. At Vrbov, the presence of female(s) and the late slaughter age of caprines (only individuals older than 2 years) suggest they were also exploited for secondary products such as milk and wool/ hair. A higher slaughter age was dominated among cattle too, but some individuals were also killed early (0.5-1 year old). This is the age when calves are being weaned. That cattle and caprines were also kept for milk and wool is also likely at Lazisko. The bones of juveniles (up to first year) and young adults (up to fourth year) prevail in the faunal assemblage. In cattle, the butchery marks clearly indicate meat exploitation, but at the same time, slaughtering weaned calves in the postlactation period (6-12 months) is evidence that dairy cows were also kept for milk production. In sheep, the earliest slaughter occurred between $6^{\text {th }}$ and $12^{\text {th }}$ month. In cattle, lactation lasts up to 300 days and the calves stay with cows to relieve the milk production, while in caprines this period is shorter, around 100-140 days, and the presence of offspring is not necessary, so the young animals can be weaned earlier (Ballase 2003). Most possibly, cattle and sheep had combined uses within the subsistence economy, probably providing both primary (meat, hide, bones, sinew and blood) as well as secondary products (milk and wool). At Vrbov, processing of animal wool/hair is also suggested by finds of shepherd shears and clay spindle whorls, although the latter may also have been used for spinning plant fibres (Pieta 1991, 384, fig. 6: 18). ${ }^{9}$ Evidence for local weaving activity was reported also from the eastern, marginal zone of the North Carpathian group, Prešov-Pavlovičovo námestie (Budinský-Krička 1963, 31, 32) and Nižná Myšla-Alamenev (Béreš et al. 1991, 175).

The bone remains showed that meat and fat was the primary focus in pig breeding in Vrbov and Lazisko. In Vrbov, the presence of a male pig at an optimal slaughter age (between its first and second year) fits with a deliberate selection of (subadult) males for slaughter and keeping females alive for breeding purposes. As evidenced by the low number of skeletal remains from horse, this species was not kept primarily for its meat but were used

\footnotetext{
6 This specimen $(145 \mathrm{~cm}$; Rajtová 1964, 267) may rather represent an aurochs, as the assessed withers height exceeds that for contemporary cattle.

7 The skeleton of an adult stallion (ca. 8-10 years old) from the early medieval cemetery in Dubovany-Pápež $\left(8^{\text {th }}-9^{\text {th }}\right.$ c. AD) served as a reference individual in the archaeozoological laboratory in Nitra.

8 https://en.wikipedia.org/wiki/Hucul_pony

9 K. Pieta, personal communication.
} 
for the transportation of commodities and people. Nevertheless, at least in Lazisko the death and consumption of young horses speaks for mixed utility. Was the slaughter of horses a deliberate act, a seasonal practice or just a coincidence? Were the young horses injured or was it a 'crisis' plan for getting some meat for people/dogs? Unfortunately, this faunal assemblage cannot provide answers although the butchery of young (subadult) horses was already noted in the faunal assemblage from Prešov-Pavlovičovo námestie (Ambros 1962). The possibility of the combined utility of equids at protohistoric sites must be studied in more detail in the future, but it is possible that except for meat, hides, bones, or milk, the hooves or hide were also exploited. Our findings provide a relatively convincing evidence that horse hide was processed at the settlement.

\section{CONCLUSIONS}

The results of archaeozoological analysis from Vrbov and Lazisko reflect a pastoral animal economy as well as the preferences of beef and sheep(goat?) meat in the diet of the North Carpathian groups settled in the mountains and valleys of northern Slovakia. The agriculture was probably based on cultivating crops and herding both large and small ruminants. Hunting for dietary reasons was not common. The variety of skeletal elements present in these assemblages, including skull, horns, terminal parts of the limbs or tail vertebrae attest that cattle and caprines (sheep) at least were kept and slaughtered locally. Domestic cattle (Bos taurus), sheep (Ovis aries) and pigs (Sus domesticus) were identified at both settlements. Horses (Equus caballus) and brown bear (Ursus arctos) have been registered only at the hilltop settlement in Lazisko. Observed carnivore gnawing marks (common in the Lazisko assemblage), also suggest that domestic dogs were present and had access to the food refuse. Unlike other contempo- rary sites in the region, no bird and fish remains have been registered. However, this may also be due to recovery and sampling techniques.

The evaluation of relative quantity of finds (NISP) has shown that people preferred beef, veal, mutton and lamb in diet. At Vrbov, caprines (42.5\%) and cattle $(39.1 \%)$ dominated the assemblage. Pigs represented only half their number (18.4\%). At Lazisko, cattle dominated (68.7\%) although caprines were relatively common $(25.2 \%)$. Pigs $(4.3 \%)$ and horses $(1.8 \%)$ occurred sporadically. Pork and horse meat probably only represented an occasional enrichment of the diet here. A single find of a brown bear canine tooth from Lazisko cannot be interpreted in terms of diet. Nevertheless, people might have killed a wild 'beast' to protect their animal herds and households from marauding animals and subsequently eat the meat of killed animals. In any case, game seems to have had negligible importance in the diet at both sites. In contrast to that, the contemporary lowland settlements in eastern (Prešov, Ostrovany, Nižná Myšla) and southwestern Slovakia (Nitra) display a much more variable meat diet with a higher percentage (3.6\% to $13.3 \%$ of NISP of mammals) of game. Most probably, a mountainous diet was simpler and contained a high proportion of dairy products. Mixed exploitation of cattle and caprines and a focus on secondary products is indicated by the dominance of subadult/adult individuals in the faunal waste and the presence of ewe and lambs, killed after being weaned (before the first winter) or between their first and second years of life. Without doubt, the milk (from cows, ewes, goats? or mares?) and its products (cheese and yoghurt) were at least seasonally available. The animal fleece/hair may have been produced that way too. Domestic textile production was indicated by finds of clay spindle whorls and a shepherd's shears in Vrbov as well as at Lazisko. The observed skinning marks on the studied horse and cattle bones also provide substantial evidence for processing of hides, horn or bone at these settlements. 


\section{BIBLIOGRAPHY}

Ambros 1978 - C. Ambros: Prírastky a analýzy archeozoologického materiálu. AVANS 1977, 1978, 19-27.

Ballase 2003 - M. Balasse: Keeping the young alive to stimulate milk production? Differences between cattle and small stock. Anthropozoologica 37, 2003, 3-10.

Benecke 1994 - N. Benecke: Archäozoologische Studien zur Entwicklung der Haustierhaltung in Mitteleuropa und Südskandinavien von den Anfängen bis zum ausgehenden Mittelalter. Schriften zur Ur- und Frühgeschichte 46. Berlin 1994.

Benediková et al. 2019 - L. Benediková/M. Furman/Z. Bielichová/J. Mihályová/J. Tirpák: Čo (staro)nového pod Rohačkou? In: L. Benediková/G. Březinová/E. Horváthová/S. Stegmann-Rajtár (eds.): Fragmenty času. Venované Elene Miroššayovej k 70. narodeninám. Študijné zvesti AÚ SAV - Supplementum 1. Nitra 2019, 51-88. DOI: https://doi.org/10.31577/szausav.2019.suppl.1.2

Benediková et al. 2020 - L. Benediková/Z. Bielichová/J. Mihályiová/K. Hensel: Sídlisko zo staršej doby rímskej v Likavke (okr. Ružomberok). In: I. Cižmář/H. Čižmářová/A. Humpolová (eds.): Jantarová stezka v proměnách času. Brno 2020, 465-500.

Béreš et al. 1991 - J. Béreš/M. Lamiová-Schmiedlová/ L. Olexa: Záchranný výskum na polykultúrnom sídlisku v Nižnej Myšli, poloha Alamenev, okr. Košice. Východoslovenský pravek 3, 1991, 166-190.

Bielichová 2019a - Z. Bielichová: Archaeozoology of the Late Roman Period Settlement at Vel'ké Zálužie in the Context of Regional Data. Slovenská archeológia 67, 2019, 61-112.

Bielichová 2019b-Z. Bielichová: Doba laténska na západnom a strednom Slovensku z pohladu archeozoológie. In: I. Bazovský/G. Březinová (eds.): L’udia a hory - archeologická perspektíva. Interakcie l'udských spoločenstiev horských a podhorských oblastí západného Slovenska. Zborník SNM. Archeológia. Suplementum 12. Bratislava - Nitra 2019, 195-238.

Bökönyi 1974 - S. Bökönyi: History of Domestic Mammals in Central and Eastern Europe. Budapest 1974.

Budinský-Krička 1963 - V. Budinský-Krička: Sídlisko z doby rímskej a stahovania národov v Prešove. Slovenská archeológia 11, 1963, 5-58.

Chroszcz et al. 2014 - A. Chrószcz/M. Janeczek/E. Pasicka/ Z. Bielichová/Z. Zawada/J. Kleckowska-Nawrot/ A. Szarek: Paleopathology of brown bears (Ursus arctos, L. 1758) from Liptovská Mara, Northern Slovakia. Research Opinions in Animal \& Veterinary Sciences 4/1, 2014, 35-39.

von den Driesch 1976 - A. von den Driesch: A Guide to the Measurement of Animal Bones from Archaeological Sites. Peabody Museum Bulletins 1. Harvard 1976.

Fabiš 2000 - M. Fabiš: Analyse der Tierreste aus der latènezeitlichen Siedlung in Nitra-Šindolka. In: G. Březinová: Nitra-Šindolka. Siedlung aus der Latènezeit. Katalog. Archaeologiae Slovaca Monographiae. Catalogi 8. Nitra Bratislava 2000, 299-334.

Fabiš 2003 - M. Fabiš: Archeozoologická analýza (1996-2000). In: Březinová a kol.: Nitra-Chrenová. Archeologické výskumy na plochách stavenísk Shell a Baumax. Katalóg. Archaeologica Slovaca Monographiae. Catalogi 9. Nitra 2003, 99-131.
Fabiš/Bielichová 2014 - M. Fabiš/Z. Bielichová: Úvodná štúdia k archeozoológii vo Vel'kom Mederi. Študijné zvesti AÚ SAV 56, 2014, 169-182.

Giertlová-Kučeráková/Soják 2002 - M. Giertlová-Kučeráková/M. Soják: Hrnčiarske pece z neskorej doby rímskej vo Vrbove. AVANS 2001, 2002, 52, 53.

Giertlová-Kučeráková/Soják 2005 -M. Giertlová-Kučeráková/ M. Soják: Novšie nálezy severokarpatskej skupiny v povodí rieky Poprad. Študijné zvesti AUU SAV 38, 2005, 113-136.

Grimm 2013 - O. Grimm: Bear skins in northern European burials (first millennium AD). In: O. Grimm/U. Schmölcke (eds.): Hunting in northern Europe until 1500 AD. Old traditions and regional developments, continental sources and continental influences. Schleswig 2013, 277-296.

Habermehl 1961 -K.-H. Habermehl: Die Altersbestimmung bei Haustieren, Pelztieren und beim jagdbaren Wild. Berlin Hamburg 1961.

Kiefer/Kolník 1995 - L. Kiefer/T. Kolník: Ďalšie nálezy severokarpatskej kultúrnej skupiny z Vrbova. AVANS 1993, 1995, 79, fig. 52.

Kolda 1936 - J. Kolda: Srovnávací anatomie zvirrat domácích se zřetelem $k$ anatomii člověka. Brno 1936.

Lamiová-Schmiedlová 1964 - M. Lamiová-Schmiedlová: Kontrolný výskum v Ostrovanoch. AVANS 1963, 1964, 233-264.

Lau/Pieta 2014 - N. Lau/K. Pieta: Das Grab von PopradMatejovce in der Slowakei - Konstruktion, Ausstattung und Wiederöffnung eines frühvölkerwanderungszeitlichen Kammergrabes. In: A. Abegg-Wigg/N. Lau (Hrsg.): Kammergräber im Barbaricum. Zu Einflüssen und Übergangsphänomenen von der vorrömischen Eisenzeit bis in die Völkerwanderungszeit. Internationale Tagung. Schleswig 25.-27. November 2010. Neumünster - Hamburg 2014, 343-364.

Lityńska-Zając 1993 - M. Lityńska-Zając: Odciski roślinne na polepie i węgle drzewne ze stanowiska a w Rytrze, woj. Nowy Sącz. In: Madyda-Legutko/Tunia 1993, 149-158.

Lyman 1994 - R. L. Lyman: Vertebrate Taphonomy. Cambridge Manuals in Archaeology. Cambridge 1994. DOI: https://doi.org/10.1017/CBO9781139878302

Madyda-Legutko/Tunia 1993 - R. Madyda-Legutko/K. Tunia: Rytro. Karpacka osada z okresu wędrówek ludów. Zeszyty Naukowe Uniwersytetu Jagiellońskiego 1118. Prace Archeologiczne 57. Kraków 1993.

Oehrl 2013 - S. Oehrl: Svá beitum vér björnuna á mörkinni norðr - Bear hunting and its ideological context (as a background for the interpretation of bear claws and other remains of bears in Germanic graves of the $1^{\text {st }}$ millennium AD). In: O. Grimm/U. Schmölcke (eds.): Hunting in northern Europe until 1500 AD. Old traditions and regional developments, continental sources and continental influences. Schleswig 2013, 297-332.

Pieta 1982 - K. Pieta: Die Púchov-Kultur. Archaeologica Slovaca Monographiae. Studia 1. Nitra 1982.

Pieta 1991 - K. Pieta: Hradisko Zvon v Lazisku. AVANS 1989, 1991, 79, 80.

Pieta 2008 - K. Pieta: Höhensiedlungen der Völkerwanderunszeit im nördlichen Karpatenbecken. In: H. Steuer/ V. Bierbrauer (Hrsg.): Höhensiedlungen zwischen Antike und Mittelalter von den Ardennen bis zur Adria. Ergänzungsbände zum Reallexikon der germanischen Altertumskunde 58. Berlin - New York 2008, 457-480. 
Pieta/Hanuliak 1988 - K. Pieta/V. Hanuliak: Výšinné sídlisko z neskorej doby rímskej v Lazisku. AVANS 1987, 1988, 111.

Pieta/Ruttkay 1986 - K. Pieta/M. Ruttkay: Výskum v Nitre-Párovských Hájoch. AVANS 1985, 1986, 191, 192.

Pieta/Ruttkay 1997 - K. Pieta/M. Ruttkay: Germanische Siedlung aus dem 4. und 5. Jh. in Nitra-Párovské Háje und Probleme der Siedlungskontinuität. In: J. Tejral/ H. Friesinger/M. Kazanski (Hrsg.): Neue Beiträge zur Erforschung der Spätantike im mittleren Donauraum. Spisy Archeologického ústavu AV ČR Brno 8. Brno 1997, 145-163.

Rajtová 1964 - V. Rajtová: Zvieracie kosti z výskumu v Ostrovanoch. Študijné zvesti AÚ SAV 13, 1964, 265-270.

Rajtová 1991 - V. Rajtová: Hodnotenie zoologického materiálu z osady v Nižnej Myšli, poloha Alamenev. Východoslovenský pravek 3, 1991, 191, 192.

Schmid 1972 - E. Schmid: Atlas of animal bones. Amsterdam London - New York 1972.
Silver 1969 - I. A. Silver: The ageing of domestic animals. In: D. R. Brothwell/E. S. Higgs (eds.): Science in archaeology. A survey of progress and research. $2^{\text {nd }}$ edition. New York 1969, 250-268.

Soják 2015 - M. Soják: Spiš. Svedectvo archeológie. Archeologica Slovaca Monographiae. Varia 4. Nitra 2015.

Štolcová et al. 2014 - T. Štolcová/D. Schaarschmidt/S. Mitschke: Textile finds from a chieftain's grave. Preliminary report from Poprad-Matejovce, Slovakia. Archaeological Textiles Review 56, 2014, 50-59.

Teichert 1975 - M. Teichert: Osteometrische Untersuchungen zur Berechnung der Widerristhöhe bei Schafen. In: A. T. Clason (ed.): Archaeozoological studies. Amsterdam - Oxford 1975, 51-69.

Tunia 1989 - K. Tunia: Umweltbedingtheiten der Agrar- und Viehzuht-Wirtschaft auf den gebirgigen Gebieten in der Urgeschichte. Casus der westkarpathischen spätkaiserzeitlichen Besiedlung. Acta Archaeologica Carpathica 28, 1989, 119-144.

\section{UNPUBLISHED SOURCES}

Ambros 1960 -C. Ambros: Prešov-Pavlovičovo námestie. Nitra 1960. Výskumná správa.

Ambros 1961 - C. Ambros: Prešov-Pavlovičovo námestie. Nitra 1961. Výskumná správa.

Ambros 1962 - C. Ambros: Prešov-Pavlovičovo námestie. Nitra 1962. Výskumná správa.

Ambros 1986 - C. Ambros: Nitra-Párovské Háje, poloha Jarok.
Nitra 1986. Výskumná správa 11596/86. Dokumentácia AÚ SAV Nitra.

Bielichová 2021a - Vrbov, poloha Vrbovský lesík. Nitra 2021. Výskumná správa 20425/21. Dokumentácia AÚ SAV Nitra.

Bielichová 2021b - Lazisko, poloha Zvon. Nitra 2021. Výskumná správa 20426/21. Dokumentácia AÚ SAV Nitra.
Manuscript accepted 8. 7. 2021

Translated by author
Mgr. Zora Bielichová

Archeologický ústav SAV

Akademická 2

SK - 94921 Nitra

zora.miklikova@gmail.com 
